\title{
EFFECT OF POTASSIUM FERTILIZER RATES \\ AND SOME PLANT EXTRACTS ON FORAGE, SEED YIELD AND SEED QUALITY OF EGYPTIAN BERSEEM UNDER SALINE SOIL CONDITIONS. \\ Aboelgoud, Sh.A.*; I.F.Mersal ${ }^{\star \star}$ and M.El.M.Haggag* \\ * Forage Crop Research Dept., FCRI, ARC, Giza, Egypt \\ ** Seed Tech. Research Dept., FCRI, ARC, Giza, Egypt
}

\section{ABSTRACT}

Field and Laboratory experiments were conducted at the experimental Farm Station of El-Serw, Damietta Governorate and Seed Technology Research Unit , Mansoura, during the season of $2013 / 2014$ and 2014/2015, to study the effect of potassium fertilization rates e.g. $0,15 \mathrm{~K} 30,45 \mathrm{~kg} \mathrm{~K} \mathrm{~K}_{2} \mathrm{O}$ and foliar spraying of some plant extracts i.e. rose water, mango and orange was used for spraying Berseem plants in each plot at flowering and seed filling stages to study the effect on forage and seed yield of berseem clover cv. Serw 1 as well as seed quality under saline soil condition.

The experimental was arranged in strip plot design with three replicates. Potassium fertilizer rates were devoted in the horizontal plot whereas, the water and some plant extracts were assigned in vertical plot. The experimental plot area was $3 \times 4 \mathrm{~m}^{2}$.

The results could be summarized as follows:

Adding potassium fertilizer rates in high portion (45 $\mathrm{kg} \mathrm{K}_{2} \mathrm{O}$ ) markedly increased green ad dry forage yields when compared with the other portions i.e. 15 and $30 \mathrm{~kg} \mathrm{~K} \mathrm{~K}_{2} \mathrm{O}$. in the first, second and third cut, respectively. The lowest value of green forage yields were observed under the control treatments (without fertilization). The highest number of heads $/ \mathrm{m}^{2}$, weight of heads $/ \mathrm{m}^{2}$ and no. of seeds/head, straw and seed yield $\mathrm{kg} / \mathrm{fed}$ increased significantly in the two seasons when plots treated with the high portion of potassium fertilizer rates, while the lowest means of the above mentioned characters were observed in control treatments. In addition, 1000-seed weight, straw yield and seed yield kg/fed didn't reach the significance of differences in the first season.

Spraying berseem with water and/or plant extracts achieved the highest mean of significance of differences in the second season for no. of heads $/ \mathrm{m}^{2}$, weight of heads $/ \mathrm{m}^{2}$, no. of seeds/head and 1000 -seed weight, straw and seed yield/fed. when using orange plant extracts.

With regard to seed quality, with increasing potassium application seed and seedlings vigor traits as measured by accelerating aging test, electrical conductivity of leached seed, seedling length, seedling dry weight and seed vigor index were the best comparing obtained seed from unfertilized plots with potassium.

The studied plant extracts had significant effects on germination percentage, electrical conductivity, seedlings dry weight and seed vigor index meanwhile the effect on accelerating test and seedling length was insignificant.

Keywords: Potassium fertilizer, Plant extracts, orange oil, Mango oil, water rose oil, forage and seed yields, seed quality

\section{INTRODUCTION}

Berseem clover or Egyptian clover (Trifolium alexandrinum, L.) is the main annual leguminous crop in Egypt. Berseem clover is high nutritional 
quality for animal feed. Berseem also contributes to soil fertility and improves soil physical characteristics (Graves et al., 1996). In Egypt berseem is cultivated through the winter season from (early October to May) for forage production and at the end of the season (late April and early May) seed crops sometimes taken (El-Nahrawy et al., 1997).

Berseem clover is a major seed export crop in Egypt. Annual exports of berseem seed have to more than 12000 tons in 2001 and the main honey producing crop (El-Nahrawy, 2005), In Egypt it is necessary to increase Berseem seed production due to increasing demands for export.

Although, plant breeders have made significant improvement in yields of many crops, limited work have been made done on yield potential or seed production in Egyptian clover improvement. Due to difficulty of improvement seed yield through traditional methods of breeding because small floral parts which make artificial hybridization so difficulty besides, high degree of self sterility and incompatibility limits the extent to which these plants may be inbred (Bakheit, 2013). Therefore, researchers face these problems through agriculture practices and used mainly selection and synthetic varieties procedures for improving seed yield.

One of the major difficulties facing berseem cultivation is the low productivity of seed at the end of the growing season where there are some factors affect seed production among them; number of cuts, length of the growth period before flowering, drought, soil salinity, whether conditions and availability of pollinators (Geweifel and Rammah 1990).

Salinity is a major abiotic stress which adversely affects plant processes at physiological, biochemical and molecular level and reduces plant productivity (Tester and Davenport, 2003 and Munns, 2002). Salinity is a becoming a major threat to plant productivity loss in agriculture system. Plants respond to saline environmentally by modulating the inherent mechanisms to adjust the change in environment. The understanding of the mechanisms that plants operate under saline environment is essential beginning in efforts to reduce the adverse effects of salinity stress. The agricultural system is tightly linked with the fertilizer input and thus the judicious application of the fertility is expected to lead positive effects in reversing the salinity (Khan et al., 2014).

Among the nutrients, potassium $(\mathrm{K})$ is a macro element known to be very dynamic and a major contributor to the organic structure and metabolic functions of the plant. Adequate $\mathrm{K}$ supply is also desirable for the efficient use of $\mathrm{Fe}$, while higher $\mathrm{K}$ application results to competition with $\mathrm{Fe}$ (Çelik et al., 2010). Potassium is not only an essential element for forage legumes but also these crops have a high level of uptake. Potassium plays a vital role in the nutrition and production of forage (Mohiti et al., 2011).

The environmental stresses resulting from drought, temperature, salinity, air pollution, heavy metals, pesticides and soil $\mathrm{pH}$ are major limiting factors in crop production (Hernandez et al., 2001). Seed yield of berseem is often reduced by high temperature at the reproductive period (Lannucci and Martiniello, 1998). Lannucci (2001) found that high temperature during the growing season of berseem clover may affect the seasonal distribution of forage and seed yields. Drought stress during flowering and seed 
composition has a great impact on seed yield where, flowering is one of the most important growth stage affected by drought stress, Mohan and Rao 1984, reported that, drought stress interferes with flower period, flower opening, nectar production, and turgor maintenance of floral organs. Seeds are living organisms, and the shelf life of the seed is affected by previous plant life cycle and factors as soil nutrition which accumulated in high amounts (during the development of the seed) to be used later during germination (Gokce, 2006), one of the mineral nutrients is potassium which has an important effect for increasing plant tolerance to water stress and activates the enzyme system. Increased potassium during the late stages of maturation increased the germinability of sorghum seed (Arnold et al., 1995). Also, seed quality is affected by drought stress which decreases germination percentage and seed vigor (germination after accelerated aging test, cold test and electrical conductivity test of seed leachates). Lannucci et al. (1996) reported that, seed vigor in berseem clover, estimated as germination after the accelerated aging test, was also reduced.

Seed quality is also another important trait affected by drought stress which decreases germination percentage and seed vigor (germination after accelerated aging test, cold test and electrical conductivity test of seed leachates). Lannucci et al. (1996) reported that, seed vigor in berseem clover, estimated as germination after the accelerated aging test, was also reduced when plants were exposed to water deficit during seed fill. (Fougereux et al., 1997). They reported that the decrease in seed quality was higher when drought stress occurred during the seed filling stage.

Many studies revealed to the importance of foliar spraying nutrients and antioxidants during flowering and seed filling stages but no studies on spraying plant extracts to deduce the harmful effect of drought, high temperature on seed yield and seed quality under salinity stress. So the aim of the present study was to investigate the effect of potassium fertilization and foliar spraying of some plant extracts on forage and seed yield of clover berseem as well as seed quality.

\section{MATERIALS AND METHODS}

Field and Laboratory experiments were conducted at the Experimental Farm Station of El-Serw, Damietta Governorate and Seed Technology Research Unit, Mansoura, during the season of 2013/2014 and 2014/2015, to study the effect of potassium fertilization rates and foliar spraying of some plant extracts on forage and seed yield of berseem clover as well as seed quality. The soil of the experimental Station was clay and physical and chemical analyses are shown in Table (1) according to Piper (1950).

Good seed bed preparation through two cross ploughing, well leveling and compacting were performed. Superphospate at the rate of $150 \mathrm{~kg} \mathrm{P}_{2} \mathrm{O}_{5}$ was used during land preparation. The land was then irrigated and puddled before sowing. Sowing took place at $18^{\text {th }}$ and $24^{\text {th }}$ in the first and second seasons, respectively. After puddling, berseem Meskawi cv. "Serw 1" seeds were hand broadcasted in the presence of thin layer of irrigation water. Four 
treatments of potassium fertilization i.e. 15,30 and $45 \mathrm{~kg} \mathrm{~K}_{2} \mathrm{O}$ in the form of potassium sulphate in four equal portions with control treatment (without addition). The first portion was added after 21 days from sowing, second, third and fourth portion were added after first, second and third cut, respectively.

Table (1): Initial physical and chemical analysis of the soil before conducting the experiment (average of the two seasons).

\begin{tabular}{|l|l|c|c|}
\hline \multicolumn{2}{|c|}{ Physical } & \multicolumn{2}{c|}{ Chemical } \\
\hline Texture & Clayey & $\mathrm{pH}$ & 7.6 \\
\hline Coarse sand & 1.44 & $\mathrm{Ec} \mathrm{ds} / \mathrm{m}$ & 5.88 \\
\hline Fine sand & 10.35 & $\mathrm{CaCO}_{3} \%$ & 1.34 \\
\hline Silt & 22.26 & $\mathrm{OM} \%$ & 0.86 \\
\hline Clay & 65.95 & Total N ppm & 32 \\
\hline \multicolumn{2}{|l|}{} & Available P ppm & 7.94 \\
\cline { 2 - 4 } & Available K ppm & 201.3 \\
\hline
\end{tabular}

The first cut was taken after 55 days from sowing in the first season and 58 days from sowing in the second seasons; the second and third cuts were taken after 40 days intervals. The experimental was laid out in a strip plot design; the vertical plots were devoted to spray treatments and potassium fertilizer rates were arranged in the horizontal plots. The plot area was $12 \mathrm{~m}^{2}(3 \times 4 \mathrm{~m})$. The preceding summer crop was rice in both seasons and seeding rate was $30 \mathrm{~kg} / \mathrm{fed}$. Berseem plants were leaved without cutting from $20^{\text {th }}$ April to seed production. Water and pant extract substances i.e. rose water, mango and orange were sprayed after 20 days from flowering and beginning of seed filling.

\section{Plant extract preparation methods:}

One hundred fifty grams of each of rose, mango and orange flowers were air dried in open -air for 5 days followed by further drying in air oven at $40^{\circ} \mathrm{C}$ for two days until constant weight. Dried flowers were ground by hand, sieved and preserved away from light and moisture until used in preparing the crude extracts. Crude extracts were prepared according to the method adopted by Freedman et al. (1979). The $250 \mathrm{gm}$ of the flowers powder were separately soaked in $1500 \mathrm{ml}$. of the solvent (Ethanol) for 4 days and filtered through Whatman No.1 filter paper over Anhydrous Sodium Sulphate. After that, the extracts were evaporated by rotary evaporator (temperature not accessed $50^{\circ} \mathrm{C}$ ). After extraction, the stock solution was prepared and a concentration of $10 \%$ from each extract (rose water, mango and orange) was used for spraying Berseem plants in each plot at flowering and seed filling stages.

\section{A: Yield traits:}

1. Forage fresh and dry yields (ton/fed): The random sample were taken from plot. These samples were cut by using a sickle and then weighed. Mean fresh weight forage yield transformed into ton/fed. Dry yield (ton/fed); the random sample of known weight $(250 \mathrm{gm})$ were taken from each plot, these samples were dried at $70^{\circ} \mathrm{C}$ for 15 hours and then at $105^{\circ} \mathrm{C}$ till it gave a constant weight, then dry forage yield per fedaan were calculated. 
2. Number of heads $/ \mathrm{m}^{2:}$ Random sample of $1 \mathrm{~m}^{2}$ from each plot were taken and accounted.

3. Weight of heads $/ \mathrm{m}^{2}$ Random sample of $1 \mathrm{~m}^{2}$ from each plot were taken and weighed.

4. Number of seeds /head Random sample of $1 \mathrm{~m}^{2}$ from each plot were taken and account the seeds/head

5.1000 -seed weight Random sample of $1 \mathrm{~m}^{2}$ from each plot were taken and accounted.

6.Straw yield $\mathrm{kg} / \mathrm{fed}$ Random sample of $1 \mathrm{~m}^{2}$ from each plot were taken and weighed then converted into $\mathrm{kg} / \mathrm{fed}$.

7.Seed yield $\mathrm{kg} / \mathrm{fed}$. Every plot was harvested individually and calculated the total seed yield to $\mathrm{kg} / \mathrm{feddan}$.

\section{B: Seed quality traits:}

Germination percentage: Germination percentage was performed according to ISTA, 1985, while 400 seeds of clover in 4 replicates were sown at $20 \circ \mathrm{C}$ \pm 2 in sterilized sand culture. Germination percentage defined as the total number of normal seedlings at the end of the test after eight days.

Accelerated aging germination test (germination after seed aging). Accelerated aging test was performed according to (ISTA, 1985). Each sample of 400 seeds were placed in an accelerate ageing chamber at $40^{\circ} \mathrm{C}$ and $100 \%$ relative humidity for $48 \mathrm{~h}$. After this exposure period, the seed sample was submitted to the Standard Germination Test.

Seedling dry weight: Ten normal seedlings were dried in a hot-air oven at $85^{\circ} \mathrm{C}$ for 12 hours (Krishnasamy and Seshu, 1990) and then weighted in (g).

Seedling length (cm): During the final count 10 normal seedlings from each replicate were taken randomly to measure the seedling length.

Electrical conductivity ( $\mu \mathrm{mohs} / \mathrm{g}$ seed). It was calculated according to Matthews and Alison (1987). Fifty seeds in four replications were weight to 2 decimal places and placed in a $200 \mathrm{ml}$ flask and $67.5 \mathrm{ml}$ of distilled water was added. The flask were covered and placed in an incubator at a constant temperature of $20 \cong \mathrm{C}$ for 24 hours, after which the contents of the flasks were gently stirred. The electrical conductivity was measured in the solution after removing the seeds. The HANNA conductivity meter ( $\mathrm{Hi} 80333)$ was used. The results were reported as $\mu$ moh per one $(\mathrm{g})$ of seed $(\mu \mathrm{mohs} / \mathrm{g}$ seed).

Seedling Vigour Index: Seedling vigour index was calculated with the help of data recorded on germination percentage and seedling growth according to International Seed Testing Association (ISTA, 1985) by the formula :

S. V. I. = Seedling dry weight $(\mathrm{g}) \times$ Germination percentage.

Collected data for each season were statistically analyzed by the technique of analysis of variance and the least significant differences (LSD) of treatments (Gomez and Gomez, 1984). Bartlett test was done to the homogeneity of error of variance. The test significant for all traits except fresh and dry weight yields and all the seed quality traits, thus the data were combined for these traits only. 


\section{RESULTS AND DISCUSSION}

\section{A: yield traits:}

1. Forage fresh and dry yields:

Data in Table (2) shows the combined analysis the effect of potassium fertilizer rates on forage fresh and dry yields of berseem. Data illustrates that the differences between forage fresh weight as affected by potassium fertilizer rates were significant in all cuts in both seasons. Adding potassium fertilizer rates in high portion ( $45 \mathrm{~kg} \mathrm{~K}_{2} \mathrm{O}$ ) markedly increased green forage yield when compared with the other portions i.e. 15 and $30 \mathrm{~kg} \mathrm{~K} \mathrm{~K}_{2} \mathrm{O}$. Application of $45 \mathrm{~kg} \mathrm{~K} \mathrm{~K}_{2} \mathrm{O}$ gave 10.20, 12.22 and 11.44 ton/fed. in the first, second and third cut, respectively. The lowest value of green forage yields $(8.16,9.27$ and 9.26 ton/fed.) were observed under the control treatments (without fertilization). The highest total forage yield can be achieved from the plots which received high portion of potassium fertilizer rates.

Table (2): Fresh and dry yields of berseem (ton/fed) as affected by different potassium rates (combined over both seasons of 2013/2014 and 2014/2015)

\begin{tabular}{|c|c|c|c|c|c|c|c|c|}
\hline \multirow{2}{*}{ Treat. } & \multicolumn{4}{|c|}{ Fresh yield (ton/fed.) } & \multicolumn{4}{|c|}{ Dry yield (ton/fed.) } \\
\hline & $1^{\text {st }}$ cut & $2^{\text {nd }}$ cut & $3^{\text {rd }}$ cut & Total & $1^{\text {st }}$ cut & $2^{\text {nd }}$ cut & $3^{\text {rd }}$ cut & Total \\
\hline Control & 8.16 & 9.27 & 9.26 & 26.69 & 1.16 & 1.45 & 1.99 & 4.61 \\
\hline $15 \mathrm{~kg} \mathrm{~K}_{2} \mathrm{O}$ & 8.89 & 10.76 & 9.85 & 29.50 & 1.22 & 1.78 & 2.07 & 5.06 \\
\hline $30 \mathrm{~kg} \mathrm{~K}_{2} \mathrm{O}$ & 9.37 & 11.71 & 10.46 & 31.51 & 1.29 & 1.85 & 2.29 & 5.44 \\
\hline $45 \mathrm{~kg} \mathrm{~K} \mathrm{~K}_{2} \mathrm{O}$ & 10.20 & 12.22 & 11.14 & 33.56 & 1.35 & 1.79 & 2.47 & 5.62 \\
\hline F-Test & $\star *$ & ** & $\star *$ & $\star *$ & $\star *$ & ** & ** & $\star *$ \\
\hline LSD 0.05 & 0.69 & 0.58 & 0.95 & 1.12 & 0.07 & 0.23 & 0.17 & 0.26 \\
\hline LSD 0.01 & 1.27 & 1.07 & 1.75 & 2.05 & 0.14 & 0.42 & 0.31 & 0.47 \\
\hline
\end{tabular}

Data in the same table shows the effect of the combined data of two seasons of dry yield of berseem under potassium fertilizer rates. The highest mean of dry weight can be observed in the third cut which recorded 2.47 ton/fed from the plants that received $45 \mathrm{~kg} \mathrm{~K} \mathrm{~K}_{2} \mathrm{O}$ while the lowest mean ordered from the plant with no fertilizer in the first cut (1.16 ton/fed.). Overall mean of the three cuts, data observed that the highest mean of berseem dry matter recorded from the high dose of potassium e.g. $45 \mathrm{~kg} \mathrm{~K}_{2} \mathrm{O}$ while the lowest mean recorded from no fertilizer plots $(4.61 \mathrm{ton} / \mathrm{fed})$. This may be attributed to potassium plays a vital role in the nutrition and production of forage legumes (Misra et al., 2012). Requirement for potassium has been reported to increase during the reproductive phase in some crops, even if the potassium content in the soil was sufficient to maintain good vegetative growth This findings agreement with (Srinivasa et al., 2010) who reported that soils with low rates of both exchangeable and non exchangeable $\mathrm{K}, \mathrm{K}$ application are required to realize the full yield potential of crops.

\section{Number of heads $/ \mathrm{m}^{2}$}

Data presented in Table (3) illustrated significant effect of potassium fertilizer rates in both seasons and impact of plant extract substances was significant in the first season only on the number of heads $/ \mathrm{m}^{2}$. The highest number of heads $/ \mathrm{m}^{2}$ recorded when the plants treated with high level of 
potassium ( 825.75 and 806.75 in both seasons). Meanwhile, the lowest number of heads $/ \mathrm{m}^{2}$ was observed in control treatments. The possible reason could be due to the fact that, there was more vegetative growth in berseem which leads to production of more heads (Beena et al., 2011).

In addition, Spraying water and plant extract did not receive the significance of difference in the first season on number of heads $/ \mathrm{m}^{2}$. Spraying orange extracts surpassed all the used plant extract in the two seasons., while rose water ranked the second in the $1^{\text {st }}$ season and water achieved the second rank in the $2^{\text {nd }}$ season. This may be attributed to Manipulation of flowering time might have considerable significance as a management tool to avoid yield reductions that might commonly occur from drought stress during anthesis in a growing region (Tewolde et al., 2006). Moreover, Flower attractiveness to pollinators can be negatively affected by drought stress, which could be attributed to many factors (Al-Ghzawi et al., 2009). Drought stressed flowers may have different food-based cues which decrease foraging made by honeybees (Pernal and Currie, 2002). The time required for flower development under drought stress was less than the time usually required by normal plants (Al-Ghzawi et al., 2009), which might reduce flower size and nectar production (Zimmerman and Pyke, 1988; Lee and Felker, 1992; Campbell 1996) and nectar sucrose content (Wyatt et al., 1992). Nonstressed flowers produced with supplemental watering increased nectar volume.

\section{Weight of heads $/ \mathrm{m}^{2}$}

With respect to weight of heads $/ \mathrm{m}^{2}$, data in Table (3) show that there was a significant effect of potassium fertilizer rates on weight of heads $/ \mathrm{m}^{2}$ in both seasons. The highest numbers of weight of heads $/ \mathrm{m}^{2}$ were recorded $(0.260 \mathrm{gm})$ when using $45 \mathrm{~kg} \mathrm{~K} \mathrm{~K}_{2} \mathrm{O}$ in the two seasons whilst, the lowest number of heads $/ \mathrm{m}^{2}$ can be noticed in the first and second seasons, respectively when plots were not fertilized. These findings may be attributed to more branching capacity of berseem with more well filled heads. The same results were founded by Beena et al. (2011) and (Paricha and Bansal, 2002, and Tiwari et al., 2003) they reported that as potassium is known to exert a special influence on formation and translocation of photosynthetic material, any deficiency of this element will lead to either shrunken or undersize seeds. As the potassium rates are raised, escalated translocation of photosynthate to the young forming seeds leads to formation of larger seeds. There are a number of reports describing the role of potassium in improving the yield and quality of the seeds in many crops.

The data presented in Table (3) revealed that spraying berseem with water and/or plant extracts had significant effect on weight of heads $/ \mathrm{m}^{2}$ in both seasons. The highest value of weight of heads $/ \mathrm{m}^{2}(853.44 \mathrm{gm}$ and $869.69 \mathrm{gm}$, in the first and second season) were obtained from spraying orange extract followed by water which recorded $775.68 \mathrm{gm}$ and $764.68 \mathrm{gm}$ in both seasons, respectively. This may be attributed the role of orange extract in pollinator attract and Flowering is one of the most important growth stage affected by drought stress. Drought stress interferes with flower period, flower opening, nectar production, and turgor maintenance of floral organs (Mohan and Rao, 1984). The trend for reduced flower size under drought 
stress is mirrored in populations of Clarkia unguiculata distributed along a natural moisture gradient (Jonas and Geber 1999). Water stress detrimentally affects flower induction, pollen production and subsequently leads to failure of fertilization and hence grain set (Saini and Westgate 2000).

\section{Number of seeds /head}

Significant effects for no. of seeds/head under different potassium fertilization were obtained in table (3). As potassium fertilization were increased from $0 \mathrm{~kg} \mathrm{~K}_{2} \mathrm{O}$ to $45 \mathrm{~kg} \mathrm{~K}_{2} \mathrm{O}$ seeds/head increased from 60.039 to 72.044 in the first season and 57.125 to 72.170 in the second one. These increase may due to Nelson (1978) believed that potassium has a positive role in plant growth under saline conditions, because this element plays an essential role in stomata movement, photosynthesis and regulation of osmotic pressure for plant. Moreover, Beena et al. (2011) The possible reason could be due to more branching capacity of berseem with more well filled heads which resulted in greater number of seeds head-

As shown in Table (3) plants extract affect significantly on no. of seeds/head in the second season only. The highest number of berseem seeds/head can be achieved when plots sprayed with orange followed water and mango extracts. Spraying water recorded (73.44 and 73.55 in both seasons), orange extracts obtained (66.93 and 66.72 in the first and second seasons) while, the lowest one can be observed from the control plots. These results are outlined with those obtained by Alqudah (2011) who reported that drought stress during reproductive stage reduced crop yield by decreasing seed yield and yield components. The reduction in crop yield under drought stress could be due to the accelerated days to flowering, shorter grain filling duration and lower accumulation of dry matter.

\section{1000-seed weight}

Data in Table (3) clear that, potassium rates had insignificant effect on 1000 -seed weight in the first year only, but it reached to $1 \%$ probability in the second one. Highest mean recorded from high portion of potassium fertilization in the first and second seasons, respectively. On the other side, control treatments recorded $3.36 \mathrm{gm}$ and $3.43 \mathrm{gm}$ in the first and second seasons, respectively. This may be attributed to that when $\mathrm{K}$ fertilizer was applied to the soil, the $\mathrm{K}$ concentration in the fertilizer zone was several times higher than rest of the soil, and $\mathrm{K}$ moved in the soil through diffusion (William, 2008 and Khajani et al., 2012). The concentration of the K in the vicinity of the root surface is lowered in response to plant uptake and a gradual $\mathrm{K}$ diffusion from non-root zone to the root zone helps to meet the $\mathrm{K}$ requirement of the crop. Many crops are known to have a higher requirement for $\mathrm{K}$ during their reproductive phase as compared to their vegetative phase

It is worthy to mention that spraying water and plant extract had insignificant effect on 1000-seed weight in the first year only, but recorded the $1 \%$ probability in the second one as shown in Table (3). Using orange extract spraying gave the greatest number of 1000 -seed weight $(3.883 \mathrm{gm}$ and 3.956 $\mathrm{gm}$ in the $1^{\text {st }}$ and $2^{\text {nd }}$ seasons, respectively).in addition, using water recorded the highest mean after orange extract spraying in the first season, but in the second one orange plant extract recorded the greatest number of 1000 -seed weight. The attractiveness of plant species to pollinators depend on flower 
and nectar characteristic such as flavor, color, nectar volume, sugar concentration and aroma. The attractiveness is important to ensure the successful transport of pollens to the stigmas of pistilate flowers by bees during nectar collection. Insect pollination regularly contributes to the increase in plant seed set (Al-Ghzawi et al,. 2009).

Table (3): Effect of potassium fertilizer rates and plant extracts on no. of heads $/ \mathrm{m}^{2}$, weight of heads $/ \mathrm{m}^{2}$, number of seeds/head and 1000 seed weight in 2013/2014 and 2014/2015 growing seasons

\begin{tabular}{|c|c|c|c|c|c|c|c|c|}
\hline \multirow[t]{2}{*}{ Treat. } & \multicolumn{2}{|c|}{$\begin{array}{c}\text { No. of } \\
\text { heads } / \mathrm{m}^{2}\end{array}$} & \multicolumn{2}{|c|}{$\begin{array}{l}\text { Weight of } \\
\text { heads } / \mathrm{m}^{2}\end{array}$} & \multicolumn{2}{|c|}{$\begin{array}{c}\text { No. of } \\
\text { seeds/head. }\end{array}$} & \multicolumn{2}{|c|}{$\begin{array}{c}1000 \\
\text { seed weight }\end{array}$} \\
\hline & \multicolumn{4}{|c|}{\begin{tabular}{|l|l|l|l|}
$2013 / 2014$ & $2014 / 2015$ & $2013 / 2014$ & $2014 / 2015$ \\
\end{tabular}} & $2013 / 2014$ & $2014 / 2015$ & $2013 / 2014$ & $2014 / 2015$ \\
\hline \multicolumn{9}{|c|}{ A: Potassium rates } \\
\hline Control & 703.90 & 716.20 & 0.227 & 0.216 & 60.039 & 57.125 & 3.366 & 3.432 \\
\hline $15 \mathrm{~kg} \mathrm{~K}_{2} \mathrm{O}$ & 741.65 & 721.75 & 0.253 & 0.240 & 65.097 & 64.180 & 3.700 & 3.605 \\
\hline $30 \mathrm{~kg} \mathrm{~K}_{2} \mathrm{O}$ & 820.00 & 786.75 & 0.232 & 0.256 & 70.814 & 72.549 & 3.676 & 3.752 \\
\hline $45 \mathrm{~kg} \mathrm{~K}_{2} \mathrm{O}$ & 825.75 & 806.75 & 0.260 & 0.260 & 72.044 & 72.170 & 3.830 & 3.844 \\
\hline F-Test & ** & $\star \star$ & ** & $\star *$ & $\star *$ & $\star \star$ & NS & ** \\
\hline LSD 0.05 & 43.04 & 37.76 & 0.016 & 0.009 & 8.602 & 7.156 & ---- & 0.199 \\
\hline LSD 0.01 & 79.00 & 69.31 & 0.030 & 0.018 & 15.791 & 13.136 & ----- & 0.364 \\
\hline \multicolumn{9}{|c|}{ B: plant extracts } \\
\hline Control & 742.88 & 724.50 & 0.223 & 0.222 & 64.41 & 61.443 & 3.497 & 3.322 \\
\hline Water & 775.38 & 764.68 & 0.253 & 0.259 & 73.44 & 73.550 & 3.576 & 3.765 \\
\hline Rose water & 775.50 & 745.31 & 0.231 & 0.223 & 63.53 & 64.887 & 3.558 & 3.576 \\
\hline Mango & 773.38 & 764.06 & 0.238 & 0.234 & 66.67 & 65.925 & 3.710 & 3.673 \\
\hline Orange & 797.00 & 790.75 & 0.271 & 0.284 & 66.93 & 66.725 & 3.883 & 3.956 \\
\hline F-Test & NS & $\star * *$ & $\star *$ & $\star \star$ & NS & $\star$ & NS & $\star *$ \\
\hline \begin{tabular}{|l} 
LSD 0.05 \\
\end{tabular} & --- & 36.83 & 0.016 & 0.009 & --- & 6.98 & --- & 0.193 \\
\hline LSD 0.01 & --- & 56.08 & 0.027 & 0.0161 & --- & 11.59 & --- & 0.320 \\
\hline \multicolumn{9}{|l|}{ Interactions: } \\
\hline \multicolumn{9}{|l|}{ C:Interaction } \\
\hline$A \times B$ & NS & NS & NS & NS & NS & NS & NS & NS \\
\hline
\end{tabular}

\section{Straw yield $\mathrm{kg} / \mathrm{fed}$}

Effect of potassium fertilizer rates on straw yield $(\mathrm{kg} / \mathrm{fed})$ during the two growing seasons are presented in Table (4).

Results in Table (4) concluded that there is a general improvement in straw yield $\mathrm{kg} / \mathrm{fed}$ ) of berseem due to the additional doses of potassium fertilizer rates. Adding $45 \mathrm{~kg} \mathrm{~K} \mathrm{O} /$ plot accompanied with greatest number (303.81 kg/fed and $295.03 \mathrm{~kg} / \mathrm{fed}$ ) of straw yield $\mathrm{kg} / \mathrm{fed}$. The decrease in straw yield can be achieved in the control treatment. This decrease can be due to the salinity effects that can lead to osmotic effect, decrease water availability, ion specific toxicity, change in nutritional balance, reduction of enzymatic and photosynthetic efficiency and other physiological disorders. Also, the salinity decreases the availability of nutrients in the soil (Cramer et al., 1991 and Lutts et al., 1999).

It is evident that average of straw yield $\mathrm{kg} / \mathrm{fed}$ affected significantly by each increase of spraying water and plant extract in the first and second seasons respectively (Table 4 ). The highest mean of straw yield $\mathrm{kg} / \mathrm{fed}$ can be observed from the plots which received spraying orange plant extracts followed by water while, the control treatments recorded the lowest mean 
(255.50 kg and $256.453 \mathrm{~kg}$ ) in the first and second seasons, respectively. Water supply affects crop growth and yield during all developmental stages.

The effect of water supply on yield is highly complex and involves processes as diverse as reproductive organs, gametogenesis, fertilization, embryogenesis, and seed development stress (Barnabas et al. 2008).

Table (4): Effect of potassium fertilizer rates and plant extracts on straw yield $\mathrm{kg} / \mathrm{fed}$ and seed yield/fed in 2013/2014 and 2014/2015 growing seasons

\begin{tabular}{|c|c|c|c|c|}
\hline \multirow{2}{*}{ Treatments } & \multicolumn{2}{|c|}{ Straw yield kg/fed } & \multicolumn{2}{|c|}{ Seed yield/fed } \\
\hline & $2013 / 2014$ & $2014 / 2015$ & $2013 / 2014$ & $2014 / 2015$ \\
\hline \multicolumn{5}{|c|}{ A: Potassium rates } \\
\hline Control & 240.78 & 250.08 & 172.94 & 175.17 \\
\hline $15 \mathrm{~kg} \mathrm{~K}_{2} \mathrm{O}$ & 244.85 & 262.58 & 229.49 & 218.05 \\
\hline $30 \mathrm{~kg} \mathrm{~K}_{2} \mathrm{O}$ & 273.85 & 280.33 & 247.08 & 243.48 \\
\hline $45 \mathrm{~kg} \mathrm{~K}_{2} \mathrm{O}$ & 303.81 & 295.03 & 265.06 & 259.48 \\
\hline F-Test & $* *$ & $\star \star$ & ** & $\star *$ \\
\hline LSD 0.05 & 25.53 & 25.70 & 55.26 & 42.32 \\
\hline LSD 0.01 & 46.85 & 40.13 & 78.91 & 77.27 \\
\hline \multicolumn{5}{|c|}{ B: plant extracts } \\
\hline Control & 255.5 & 256.45 & 205.79 & 197.29 \\
\hline Water & 265.41 & 281.04 & 237.58 & 231.24 \\
\hline Rose water & 265.00 & 266.81 & 225.03 & 210.94 \\
\hline Mango & 258.72 & 273.33 & 205.05 & 218.87 \\
\hline Orange & 284.47 & 284.89 & 269.76 & 262.13 \\
\hline F-Test & ** & ** & NS & ** \\
\hline LSD 0.05 & 15.00 & 19.35 & $\begin{array}{ll}--- \\
\end{array}$ & 41.86 \\
\hline LSD 0.01 & 21.99 & 32.13 & ---- & 68.43 \\
\hline \multicolumn{5}{|l|}{ C: Interaction } \\
\hline $\mathrm{A} \times \mathrm{B}$ & NS & NS & NS & NS \\
\hline
\end{tabular}

\section{Seed yield $\mathbf{k g} / \mathrm{fed}$}

With regard to seed yield/fed., data in Table (4) show that there was a significant effect of potassium fertilizer rates on seed yield/fed. in both seasons. The highest seed yield/fed was recorded $(265.06 \mathrm{~kg}$ and 259.48 $\mathrm{kg} / \mathrm{fed}$ ) when using $45 \mathrm{~kg} \mathrm{~K} \mathrm{~K}_{2} \mathrm{O}$ in the two seasons whilst, the lowest number of heads $/ \mathrm{m}^{2}$ can be noticed in the first and second seasons, respectively when plots were not fertilized. These findings may be attributed to potassium is known to exert a special influence on formation and translocation of photosynthetic material, any deficiency of this element will lead to either shrunken or undersize seeds. As the potassium rates are raised, escalated translocation of photosynthate to the young forming seeds leads to formation of larger seeds. There are a number of reports describing the role of potassium in improving the yield and quality of the seeds in many crops (Tiwari et al., 2003). Also, This might be due to the fact that higher number of plants emerged with more branches, better filled heads and sound and plump seeds which in turn yielded more seed in berseem (Beena et al., 2011) .

It is evident that average of seed yield $\mathrm{kg} / \mathrm{fed}$. as affected significantly by each increase of spraying water and plant extract in the first season. The highest mean of seed yield $\mathrm{kg} / \mathrm{fed}$. can be observed from the plots which 
received spraying orange extract followed by water while, the control treatments recorded the lowest mean (205.79 and $197.29 \mathrm{~kg} / \mathrm{fed})$ in the first and second seasons, respectively. This may be attributed to Drought stress imposed on plants leads to decrease yield through reducing seed set (AlGhzawi et al. 2009). Low seed set percentages are regularly related to several factors such as reducing pollen grain availability. Regarding to treating plant with plant extracts, Zvedenok (1996) who reported that treating the onion with secondary attractants (citral gerniol, limone, carrot seed extract.. etc) can significantly improve pollination, citral at $0.1-0.3 \%$ having the greatest effect.

\section{B. Seed quality}

Presented data in Table (5) show the effect of the studied treatments on Egyptian berseem seed quality traits. Potassium application had significant effects on the studied traits. Obtained seeds from adding potassium, surpassed obtained seeds from unfertilized plots in seed quality traits especially by adding potassium with rate $45 \mathrm{~kg} / \mathrm{fed}$. Germination percentage reached $96 \%$ comparing $93 \%$ for control. Also, with increasing potassium application seed and seedlings vigor traits as measured by accelerating aging test, electrical conductivity of leached seed, seedling length, seedling dry weight and seed vigor index were the best comparing obtained seed from unfertilized plots with potassium. The elevated carbohydrate concentrations in source tissues under K deficiency conditions might partly due to a reduction in the amount of photosynthate available for reductive skins. Accordingly, $\mathrm{K}$ deficiency decreases quantity and quality yield (Pettigrew, 1999). El-Hawary et al. (2008) was in harmony with the previous mentioned discussion

From Table (5), the studied plant extracts had significant effects on germination percentage, electrical conductivity, seedlings dry weight and seed vigor index meanwhile the effect on accelerating test and seedling length was insignificant. Germination percentage for obtained berseem seed from sprayed plants with the studied plant extracts reached $95 \%$ comparing $93 \%$ for control. Electrical conductivity for the sprayed seed was less than control whereas seedling dry weigh and seed vigor index for sprayed plants were $0.057 \mathrm{gm}$ and 5.37 comparing $0.053 \mathrm{gm}$ and 4.99 respectively, for control. These findings in harmony with some researchers they reported that the decrease in seed quality was higher when drought stress occurred during the seed filling stage. Moisture stress imposed upon four forage legumes, berseem clover (Trifolium alexandrium L.), crimson clover ( $T$. incarnatum L.), Persian clover ( $T$. resupinatum L.) and squarrosum clover (T. squarrosum L.), reduced yield and yield components but had no effect on germination, germination rate index, seedling growth rate, and accelerated aging test lannucci et al. (1996). The enhancement of seed quality traits by spraying water and plant extracts during late stages (flowering and seed composition) may be attributed to decreasing the harmful effects of drought during these periods where drought produce smaller seed size contain less starch reserves which potentially reduced germination capacity and less seedling vigor (Nigel and Jan, 2000). 
Table (5): Effect of Potassium rates and plant extracts on germination percentage. Germination aging\%, seedlings dry weight, seedlings length, electrical conductivity Umhos/g/seed and seedling vigor index, of Egyptian berseem seed (Combined data over both seasons).

\begin{tabular}{|c|c|c|c|c|c|c|}
\hline Treatments & $\begin{array}{c}\text { Germination } \\
\%\end{array}$ & $\begin{array}{l}\text { Germination } \\
\text { aging } \%\end{array}$ & $\begin{array}{c}\text { Seedling } \\
\text { dry } \\
\text { weight(g) }\end{array}$ & $\begin{array}{l}\text { Seedling } \\
\text { length } \\
\text { (cm) }\end{array}$ & \begin{tabular}{|c|} 
Electrical \\
conductivity \\
Umhos/g/seed
\end{tabular} & $\begin{array}{l}\text { Seed } \\
\text { vigor } \\
\text { index }\end{array}$ \\
\hline \multicolumn{7}{|c|}{ A: Potassium rates } \\
\hline $0 \mathrm{~kg} \mathrm{~K}{ }_{2} \mathrm{O}$ & 93 & 77 & 0.155 & 11.2 & 0.053 & 4.45 \\
\hline $15 \mathrm{~kg} \mathrm{~K}_{2} \mathrm{O}$ & 95 & 78 & 0.151 & 11.6 & 0.055 & 5.20 \\
\hline $30 \mathrm{~kg} \mathrm{~K}_{2} \mathrm{O}$ & 95 & 79 & 0.151 & 11.6 & 0.056 & 5.32 \\
\hline $45 \mathrm{~kg} \mathrm{~K}_{2} \mathrm{O}$ & 96 & 80 & 0.150 & 11.7 & 0.057 & 5.54 \\
\hline F-Test & $\star *$ & $\star *$ & $\star \star$ & $\star *$ & $\star *$ & $\star * *$ \\
\hline LSD 0.05 & 0.24 & 0.38 & 0.0006 & 0.0052 & 0.002 & 0.045 \\
\hline LSD 0.01 & 0.28 & 0.43 & 0.0009 & 0.0072 & 0.006 & 0.049 \\
\hline \multicolumn{7}{|c|}{ B: plant extracts } \\
\hline Control & 93 & 78 & 0.153 & 11.4 & 0.053 & 4.99 \\
\hline Water & 95 & 79 & 0.151 & 11.6 & 0.056 & 5.36 \\
\hline Rose water & 95 & 78 & 0.151 & 11.5 & 0.055 & 5.24 \\
\hline Mango & 95 & 79 & 0.151 & 11.5 & 0.056 & 5.29 \\
\hline Orange & 95 & 79 & 0.151 & 11.6 & 0.057 & 5.37 \\
\hline F-Test & NS & NS & $\star \star$ & NS & $* *$ & $\star * *$ \\
\hline LSD 0.05 & 0.88 & ---- & 0.002 & ---- & -- & 0.16 \\
\hline LSD 0.01 & 1.63 & $\begin{array}{ll}--- \\
\end{array}$ & 0.003 & $\begin{array}{ll}--- \\
\end{array}$ & --- & 0.29 \\
\hline \multicolumn{7}{|l|}{ C:Interaction } \\
\hline $\mathrm{A} \times \mathrm{B}$ & NS & NS & NS & NS & NS & NS \\
\hline
\end{tabular}

From the same Table (5), interaction between potassium application and plant extracts spraying had insignificant effects on the studied traits

\section{REFERENCES}

Al-Ghzawi AA, S. Zaitoun; H.Z. Gosheh and A.M. Alqudah (2009). The impacts of drought stress on bee attractively and flower pollination of Trigonella moabitica (fabaceae). Arch Agron Soil Sci., 55(6):683-692.

Alqudah , A.M..; H.N. Samarah, and E.M. Russell (2011). Drought Stress Effect on Crop Pollination, Seed Set, Yield and Quality. Springer Science+Business Media B.V. 193-212. (C.F CD Computer search).

Arnold, R.L..B; M. Fenner and P.J. Edwards (1995). Influence of potassium nutrition on germinability abcisic acid content and sensitivity of the embryo to abcisic acid in developing seeds of sorghum bicolor (L) Moench. New Phytologist , 130(2):207-216.

Bakheit, B.R. (2013). Egyptian clover (Trifolium alexandrinum,L.) breeding in Egypt: A Review. Asian J. of Crop Science, 1-11.

Barnabas B, K. Jager and A. Feher (2008) The effect of drought and heat stress on reproductive processes in cereals.Plant Cell Environ, 31:11-3 
Beena, S., G. Hasina, W. Said, D. Yasser, H. Bibi, A. Muhammad, M. Ali, S. Ahmad and A. ljaz (2011). Effect of phosphorus and potassium on seed production of berseem. African Journal of Biotechnology 10(63): 13769-13772.

Campbell DR (1996) Evolution of floral traits in a hermaphroditic plant: field measurements of heritability and genetic correlations. Evolution, 50:1442-1453.

Çelik H; B.B. Asik; S. Gürel and A.V. Katkat (2010). Potassium as an intensifying factor for iron chlorosis. Int. J. Agric. Biol. 12: 359-364.

Cramer GR, Epstein E, Lauchli A (1991). Effect of sodium, potassium and calcium on salt-stressed barley. II. Elemental analysis. Physiol. Plant. 81: 197-202.

El-Hawary, M. A.; A. A. M. El- Emam and I. F. Mersal (2008). Effect of irrigation intervals and potassium fertilizer rates on yield and seed quality of some sorghum cultivars. J. Agric. Sci. Mansoura Univ., 33 (5): 3151-3165.

El-Nahrawy, M.A.Z (2005). The vital role of Egyptian clover in Agriculture. Proc. of 11th Conf. of Agronomy, November 15-16, 2005 Asuit Univ., Assuit Egypt, 55-62.

El-Nahrawy, M.A; A.Rammah and O. Niemelainen (1997).forage seed production in Egypt for domestic market and for export. Seed Production and Management, Tropical. ID No. 1341.pp 1-2.

Fougereux J, T. Dore; F. Labdonne and A. Fleury (1997) Water stress during reproductive stages affects seed quality and yield of pea (Pisum sativum). Crop Sci 37:1247-1252

Freedman, B. ; J. Noak and W. F. Kwolek (1979). Abioassay forplant derived pest control agent using the European cornborer.J. Entomol., 72:45-54.

Geweifel, H.G.M. and A.M.Rammah (1990). Seed production of Egyptian clover cultivars as influenced by cutting system and $\mathrm{K}$ fertilization. Zagazig Agric. Res., 17(3):589-598.

Gokce, O. (2006). Identification of zinc binding proteins of wheat seed. M.Sc. Thesis, Graduate School of Engineering and Natural Sci., Sabanci Univ. (C.F. Computer Search).

Gomez, A.A. and K.A. (1984). Statistically Procedures for Agricultural Research. $2^{\text {nd }}$ ed. John Wiley and Sons

Graves, W.L.; W.A. Williams and C.D. Thomsen (1996). Berseem clover: A winter annual forage for California agriculture. University of California Division of Agriculture and Natural Resources, Pub. No 21536: P 12.

Hernandez, J.A; M.A. Ferrer; A. Jimenez; A.R. Barcelo and F. Sevilla (2001) Antioxidant system andproduction in the apoplast of Pisum sativum $\mathrm{L}$. leaves: its relation with $\mathrm{NaCl}$-induced necrotic lesions in minor veins. Plant Physiol 127:817-831

I. S. T. A. (1985). International Rules for Seed Testing, Seed Science and Technol., 13 (2): 421-463.

Jonas C.S and M.A. Geber (1999) Variation among populations of Clarkia unguiculata (Onagraceae) along altitudinal and latitudinal gradients. Am. J. Bot. 86:333-343 
Khajani FP; H. Irannezhad; M. Majidian and H. Oraki (2012). Influence of different levels of nitrogen, phosphorus and potassium on yield and yield components of flax seed oil (Linum usitatissimum L.) variety Lirina. J. Med. Plants Res., 6(6),: 1050-1054.

Khan, N.A.; M. I. R. Khan; M. Asgher; M. Fatma, A. Masood and Sh. Syeed (2014). Salinity Tolerance in Plants: Revisiting the Role of Sulfur Metabolites J. Plant Biochem. Physiol., 2:1-8

Krishnasamy, V. and D. V. Seshu (1990). Phosphine fumigation influence on rice seed germination and vigor. Crop Sci. $30: 28-35$.

Lannucci, A. (2001) effect of harvest management on growth dynamics, forage and seed yield in berseem clover. Eur. J.Agron, 14:303-314.

Lannucci A; G. Ronga; N.D. Fonzo and P. Martiniello (1996) Effect of moisture stress on seed yield and quality of four annual clovers. J Appl Seed Prod., 14:25-29

Lannucci, A. and P. Martiniello (1998) Analysis of seed yield components of four Mediterranean annual clover. Field Crops Res., 55:235-243.

Lee S.G and P. Felker (1992) Influence of water/heat stress on flowering and fruiting of mesquite (Prosopis glandulosa var. glandulosa). J. Arid Environ., 23:309-319.

Lutts S, Bouharmont J, Kinet JM (1999). Physiological characterization of salt-resistant rice (Oryza sativa L.) somaclones. Aust. J. 47: 835-849

Matthews, S. and A. P. Alison (1987). Electrical conductivity test methods $\left(2^{\text {nd }}\right.$ edition), 37-43. published by ISTA.

Misra, S.M.; Niranjan, K.P. and Pandey, H. C. (2012). Effect of potassium application and crop geometries on seed yield, seed quality in berseem (Trifolium alexandrium L.) plants. Agricultural Science Research Journal, 2(6) pp. $324-328$.

Mohan R.H.Y and I.V. Rao (1984) Physiology of flower bud growth and opening. Proc Indian Acad Natural Sci 93:253-274

Mohiti, M., M.M. Ardalan; A.T. Mohammadi and V.H. Shokri, (2011). The efficiency of potassium fertilization methods on the growth of rice (Oryza sativa L.) under salinity stress. African Journal of Biotechnology, 10(71):15946-15952.

Munns, R. (2002) Comparative physiology of salt and water stress. Plant Cell. Environ 25: 239-250.

Nelson, W.L (1978). Influence of K on tolerance to stress (North American experience). In Sekhon GS (Ed.) Potassium in soils and crops Potash Res. Inst. of India. New Delhi. pp. 203-211.

Nigel, P. and E. Jan (2006). Cereal seed quality after drought. NSW DPI (C.F. Computer Search).

Paricha N.S and K.S. Bansal (2002). Potassium for sustainable crop production. Potash Research Institute of India, Gurgaon, Haryana, India. pp. 499-516

Pernal S. F and R.W. Currie (2002) Discrimination and preferences for pollen-based cues by foraging honeybees, Apis mellifera L. Anim. Behav., 63:369-390

Pettigrew, W.T. (1999). Potassium deficiency increases specific leaf weights of leaf glucose levels in field grown cotton. Agron. J., 91:962-968. 
Piper, C.S. (1950). Soils and Plant analysis. Interscience Publisher, Inc., New York.

Saini, HS and M.E. Westgate (2000) Reproductive development in grain crops during drought. Adv. Agron 68:59-96

Srinivasa, R.; R.Ch. Subba; AK.V, Rao, B. Venkataeswarlu; A.K Singh (2010). Categorization of districts based on non exchangeable potassium. Implications in efficient $\mathrm{K}$ fertility management in Indian Agriculture. Indian J. Fert., 6: 40-54.

Tester, M and R. Davenport (2003) $\mathrm{Na}+$ tolerance and $\mathrm{Na}+$ transport in higher plants. Ann Bot 91: 503-527.

Tewolde. H; J .C. Fernandez; A.C. Erickson (2006) Wheat cultivars adapted to post-heading high temperature stress. J Agron Crop Sci 192:111120

Tiwari ,K.N. and S. Gavin (2003). Research highlights 2002-03. Potash Research Institute of India, Gurgaon, Haryana, India. P36-37.

William, T P. (2008). Potassium influences on yield and quality production for maize, wheat, soybean and cotton. Physiologia Plantarum, 133: 670681

Wyatt, R.; S.B. Broyles and G.S. Derda (1992) Environmental influence on nectar production in milkweeds (Ascelpias syriaca and $A$. exaltata). Am J Bot 79:636-642

Zimmerman, M. and G.H. Pyke (1988) Experimental manipulations of Polemonium foliosissimum: effects on subsequent nectar production, seed production and growth. J. Ecol., 76:777-789

Zvendenok, A.P. (1996). The onion seed can be improved. Kartofel'i Ovoshchi, 4: 29. (C.F. Computer Search). 


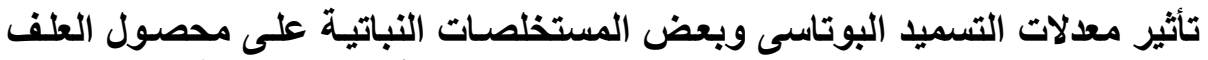

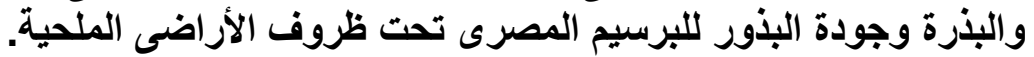

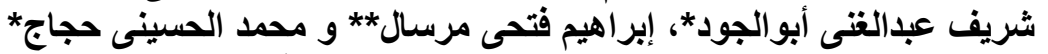

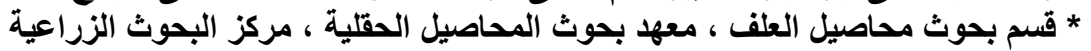
** قسم بحوث تكنولوجيا البذور ، معهذ بحوث المحاصيل الحقلية ، مركز البحوث الزئ الزراعية الزية

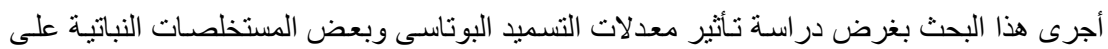

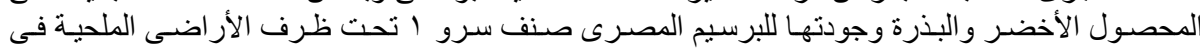

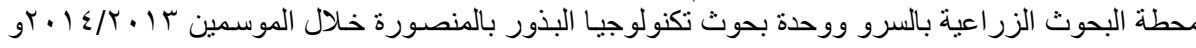
r. $10 / r \cdot 1 \leq$

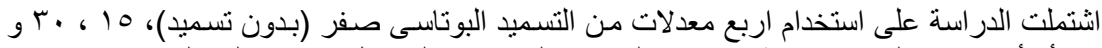

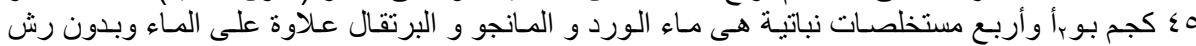

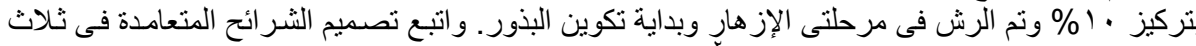

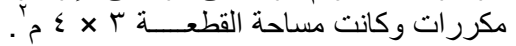

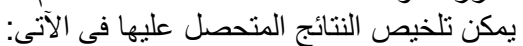

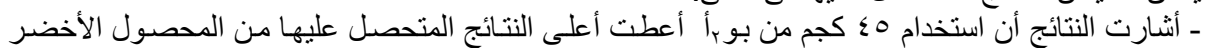
و الجـاف خـلال الحشـات المختلفة وكانت أقل النتائج هى القطع التجريبية التى لم تتلقى أى تسميد (معاملـة

المقارنة).

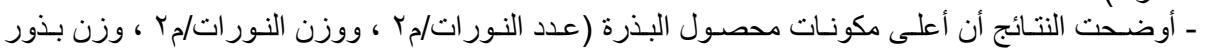

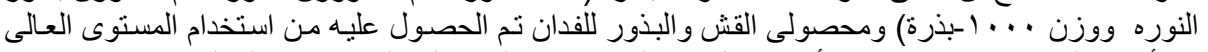

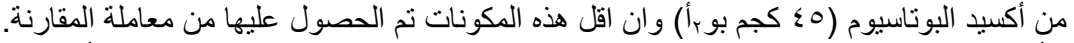

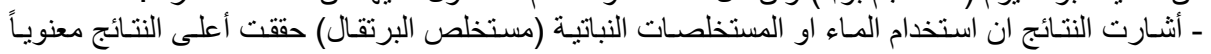

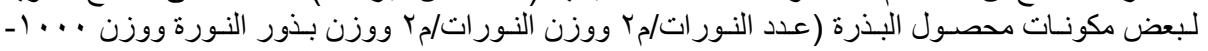

- حققت نتائج جودة البذور (قوة البادرة المقاس بإختبار الثنيخوخة و درجة التوصيل الكهربائى لمنقوع البذور

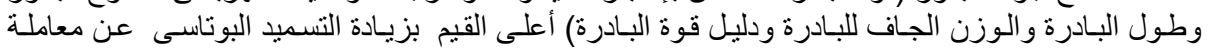

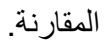

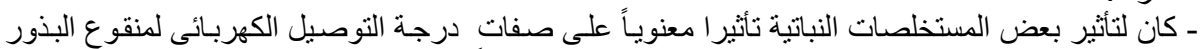

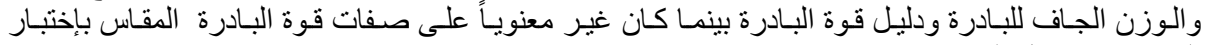
الثيخوخة وطول البادرة. 